УДК 657.37: 336.67

DOI 10.35433/ISSN2410-3748-2019-1(24)-2

Т.В. Боцян, к.е.н. доцент доцент кафедри економіки, менеджменту і маркетингу Житомирський державний університет імені Івана Франка

Л.В. Зварич, ст. викладач кафедри бухгалтерського обліку та аудиту Одеський національний економічний університет

\title{
СОЦАЛЬНИЙ КАПІТАЛ В ІНДУСТРІЇ ГОСТИННОСТІ: ОБЛІКОВИЙ АСПЕКТ
}

У статті розглянуто теоретичні засади облікового відображення сочіального капіталу. Визначено особливості сочіального капіталу як об'єкта бухгалтерського обліку. Встановлено, щзо оскільки соиіальний капітал - сукупність соиіальних зв'язків $і$ відносин, які можуть накопичуватися і витрачатися, то ие по суті не капітал, а ресурс. В роботі визначено особливості даного ресурсу на мікро і макрорівнях.

Визначено, що ті об 'єкти сочіального капіталу, щуо є об'єктами права інтелектуальної власності можемо віднести в обліку до соціальних нематеріальних активів. Визначено, щуо доцільно використовувати термін «зміџнення» чи «культивування» сочіального капіталу, тобто створення умов для його збереження $i$

розвитку замість понять «створення» чи «формування» соціального капіталу. Встановлено, щчо сочіальний капітал забезпечує створення цінності через відносини суб'єкта бізнесу з іншими особами, основою яких є довіра. Довіра в сфері готельного

бізнесу між представниками бізнесу і партнерами та клієнтами може бути забезпечена лише в разі 1) надання якісних послуг; 2) за рахунок постійної активність в сфрері $K C B$.

Ключові слова: сочіальний капітал, соџіальний ресурс, індустрія гостинності, довіра, цінності, якість, КСB

\section{SOCIAL CAPITAL IN THE HOSPITALITY INDUSTRY: ACCOUNTING ASPECT}

The article deals with the theoretical principles of social capital accounting. The features of social capital as an object of accounting are determined. Established that since social capital

is set of social ties and relationships that can accumulate and spend, then this is not essentially a capital, but a resource. The work specifies the features of this resource on the micro and macro levels. It is determined that those objects of social capital, which are objects of intellectual property right, can be considered as a social intangible assets. It is determined that it is expedient to use the term "strengthening" or "cultivating" social capital, that is, creating conditions for its preservation and development instead of the concepts of "creation"

() Боцян Т. В., Зварич Л. В. 
or "formation" of social capital. It has been established, that social capital ensures the creation of value through the relationship of the business entity with other persons, based on trust. Trust in the sphere of hotel business between business representatives and partners and clients can be ensured only in the case of 1) of quality services providing; 2) due to constant activity in the sphere of CSR.

Key words: social capital, social resource, hospitality industry, trust, values, quality, CSR

Постановка проблеми. В індустрії гостинності відбувається перехід від управління якістю послуг до відносин з приводу цієї якості. Завданням галуз є не просування готельної послуги, а розширення бази постійних клієнтів, підрядників, партнерів. Такі зміни зумовлені зміною поняття якість, яке згідно міжнародних стандартів ISO трактується як задоволеність зацікавлених сторін; тобто акцент якості зміщується від самої послуги до відносин з приводу цієї послуги. Тобто, на перший план виходять такі характеристики якості, які реалізуються через соціальний капітал, а саме довіру сторін одна до одної. Тобто, якість в готельному бізнесі визначається якістю відносин і довірою між сторонами, а ці поняття лежать в площині соціального капіталу.

Актуальність теми, в цьому контексті, обумовлена тим, що в обліку поняття якості послуг та соціального капіталу малодосліджене, більше того відсутні дослідження щодо процесу формування та оцінки якості соціального капіталу в готельному бізнесі.

Аналіз останніх досліджень і публікацій. Основну теоретикометодологічну базу концепції соціального капіталу сьогодні становлять роботи П. Бурдьє, М. Вулкока, Дж. Коулмана, А. Портеса, Р. Патнама і ін. Серед вітчизняних науковців дане питання досліджують В. Геєць, М. Горожанкіна, О. Грішнова, Т. Заяць, А. Колот, Е. Лібанова. В роботах зазначених вчених розглядаються загальнотеоретичні проблеми соціального капіталу та проводиться виділення двох теорій: індивідуального (Р. Барт, П. Бурдьє та ін.) та колективного (Дж. Коулман, Р. Патнам та ін.) соціального капіталу. Варто також відмітити Дж. Ленгеля, 
що досліджував роль соціального капіталу в досягненні підприємницького успіху.

Обліковий аспект соціального капіталу досліджували О.О. Осадча, О.Б. Сивак, Ю.А. Судин, В.В. Травін, І.А. Юхименко-Назарук.

Проте до теперішнього часу існує лише порівняльно невелика кількість публікацій, присвячених емпіричному аналізу ролі соціального капіталу в господарській практиці та методикам його формування і обліку.

Мета статті. Визначення організаційно-економічних особливостей соціального капіталу в індустрії гостинності, що дозволили б відображати його в обліку.

Робоча гіпотеза полягає в тому, що створення готельної послуги, що направлена на задоволення потреб клієнта, об'єктивно передбачає формування соціального капіталу і довіри, як його основи. Крім цього формуванню соціального капіталу сприяє корпоративна соціальна відповідальність.

Обмеженість даного дослідження визначається колективним соціальним капіталом, адже лише він досліджується у даній роботі.

Виклад основного матеріалу. Вперше термін «соціальний капітал» був використаний в 1916 р Лідою Джадсон Хеніфен для опису шкільних центрів сільських громад. Пізніше цей термін був використаний у праці «Життя і смерть великих американських міст», де вказувалось, що щільна мережа соціальних зав’язків, які існували в більш старих кварталах утворювала форму соціального капіталу, яка сприяла громадській безпеці. Економіст Глен Лаурі, як і соціолог Айвен Лайт, використовували термін «соціальний капітал» в 70-х рр. для аналізу проблеми економічного розвитку всередині міст (порівняння зв'язків довіри і соціальної приналежності у різних етнічних груп) [12, с. 34].

Проте класиками теорії соціального капіталу залишаються П. Бурдьє, Дж. Коулман і Р. Патнам. Для Колемана, соціальний капітал був як засіб (C) Боцян Т. В., Зварич Л. В. 
розуміння відносин між освітніми досягненнями і соціальною нерівністю. Його емпіричний внесок зосереджений на саме цих питаннях, хоча деякі 3 його прикладів відносяться до інших сфер [15, с. 5]. Роберт Патнам популяризував концепцію соціального капіталу [15, с. 8]. Патнам пропонує наступну дефініцію соціального капіталу «під соціальним капіталом я розумію наступні риси соціального життя - мережі, норми і довіру, що забезпечує учасників діяти разом більш ефективно щоб просувати загальні цілі» [15, с. 9].

Як зазначає Варинський В.О. [3, с. 12] «дослідниками різних країн світу розроблена низка принципово відмінних концептуальних підходів до визначення базового (родового) концепту «соціальний капітал». Автор визначає групи авторів які:

1) виходять $з$ поняття «довіра» при визначення цього поняття (Ф. Адам, Д. Подменік, С. Нака і П. Кіфера, Р. Патнам [7, 8] та ін. В Україні подібними дослідженнями займались Г. Андрущенко [1] та Т. Неделчева

2) виходить із наявності в суспільстві соціальних мереж та зв'язків між індивідами (П. Бурд’є, Дж. Коулман, В. Радаєв [10], Ф. Фукуяма, П. Шихірєв та ін.)

3) використовують як засіб для вимірювання соціальної нерівності (Н. Давидова, А. Красилова та ін.)

Сдиного, загальноприйнятого визначення соціального капіталу не існує. Виділено тільки його основні складові: довіра, ціннісні установки, соціальні мережі. Проте ці компоненти в концепціях окремих дослідників соціального капіталу присутні лише вибірково. Виходячи з цього, в рамках даної роботи, ми будемо трактувати соціальний капітал як «якість соціальних відносин», оскільки реалізовується він у взаємовідносинах.

Втіленість у відносинах вказує на природу соціального капіталу, яка проявляється в тому, що цей феномен виражає зв’язки між людьми та сформовані в них взаємини довіри. При чому мова йде не просто про (С) Боцян Т. В., Зварич Л. В. 
звичайні чи будь-які зв'язки, а про специфічні, які пов'язані, по-перше, 3 очікуваннями певної поведінки від залучених до цих зв'язків людей, подруге, з їх певними взаємними зобов'язаннями [3, с. 17-18]. Оскільки соціальний капітал - сукупність соціальних зв'язків і відносин, які можуть накопичуватися і витрачатися, то це по суті не капітал, а ресурс.

У той час як фізичний ресурс можна фізично відчути (він втілений у матеріальних цінностях), то соціальний ресурс $є$ нематеріальним, оскільки уособлює відносини. При цьому ці відносини формують додану вартість, тобто призначені крім іншого для отримання прибутку. Таким чином, за своєю сутністю «соціальний капітал» є не капіталом, а радше соціальний нематеріальний ресурс. Тут ми погоджуємось 3 позицією, що «за своїм змістом мережевий капітал слід розглядати як один із видів інтелектуального капіталу підприємства, що відображається в обліковій системі підприємства у вигляді нематеріальних активів» [14, с. 161]. Наявність даного ресурсу мінімізує транзакційні витрати. Як результат і власники готелю i його клієнти, що отримали послугу набувають порівняльну перевагу в конкурентній боротьбі по відношенню до тих, хто знаходиться за межами радіусу довіри. Це на мікроекономічному рівні.

На макроекономічному рівні ефективним $є$ розширення «кола довіри». У цьому випадку соціальний ресурс набуває виразної форми суспільного блага, яке в свою чергу виводить нас в іншу область - в проблематику довіри, як виконання обов'язків без застосування санкцій. Тобто при виконанні взаємних обов'язків санкції застосовані не будуть. В основі довіри лежить реципрокність, тобто віра у дію взаємних стосунків.

Довіра - це очікування, що виникає у членів спільноти відносно того, що інші іiі члени будуть вести себе передбачувано, чесно і з увагою до потреб оточуючих, відповідно до деяких загальних норм [13, с. 53]. До числа таких норм входять професійні стандарти і корпоративні кодекси етики. За умови відсутності довіри можуть бути використані правові (С) Боцян Т. В., Зварич Л. В. 
норми, проте найбільш дієві організації об'єднані загальними етичними цінностями. В цьому випадку не потрібна детальна правова регламентація, оскільки існує взаємна довіра.

Поняття довіри визначити в економічній площині досить важко, що обумовлено складністю моделювання зв’язків між людьми і інституційною репутацією. Проте, цей зв'язок має бути вивчений, як основа соціального капіталу. Найбільшу увагу довірі було приділено в працях Ф. Фукуями, який описав саме поняття, порядок його формування і економічне та соціальне значення. Довіру він визначає як «очікування, які породжуються у в спільнотах з регулярною, чесною і кооперативною поведінкою, що базується на нормах, які поділяються спільнотою...при цьому ці спільноти не потребують контрактного i законодавчого регулювання їх взаємовідносин, тому що пріоритет моральних цінностей дає членам групи основу для взаємної довіри [18, с 26].

Ф. Фукуяма виводить соціальний капітал із культури співробітництва, що є невидимою умовою ринку і ліберальної демократії. Він вбачає економічну функцію соціального капіталу в зменшенні транзакційних витрат, пов'язаних 3 формальними механізмами координування, наприклад, iз контрактами та бюрократичними процедурами [3, с. 35]. Фукуяма пише про те, що на ринку культура радикального індивідуалізму сприяє прогресу та інноваціям, але, iіi поширення в сфері соціальних норм призвело до руйнування чи ослаблення зв'язків, що скріплюють індивідів. Як наслідок, багато людей інтуїтивно вважають, що капіталізм погано впливає на мораль. Ринки перетворюючи все в товар замінюють соціальні контакти ринковим інтересом. 3 цієї точки зору, сучасне суспільство споживає більше соціального капіталу, ніж виробляє. Такі феномени, як зменшення довіри до суспільних інститутів, зменшення радіусу довіри, більш висока злочинність i розрив зв'язків демонструють тривожну тенденцію: (С) Боцян Т. В., Зварич Л. В. 
витрачання соціального капіталу без можливості його відтворення, адже довіра, як основа соціального капіталу не може виникнути в результаті дій окремої людина, але вона виростає 3 пріоритету суспільних чеснот над індивідуальними. Соціальний капітал і внутрішні неформальні норми стають все більш значущими, адже колективи, де завдяки високому рівню соціального капіталу панує довіра, здатні організовувати роботу людей на колективних засадах в більш гнучкому режимі, зі здатністю делегувати більше відповідальності на нижчий рівень.

Виходячи 3 цього робимо припущення, що довіра $\epsilon$ позитивною морально-етичною, прагматичною або емоційною оцінкою, соціальним суб'єктом деякого об’єкта з позицій його надійності та відповідності очікуванням суб'єкта; вона виступає орієнтацією на дію, імпульсом до взаємодії та характеризує готовність суб’єкта до кооперації.

Тут варто відмітити три перспективи довіри у складі соціального капіталу, яке в 1974 р. сформулював Алан Фокс у своїй праці «Поза контрактом: праця, влада і відносини довіри» [17]:

1) інституціоналізована довіра (визнаючи, що довіра це особисте поняття, він зазначає що вона втілюється в правила, ролі і зв’язки, які нав’язані окремими особами або очікуються, що будуть дотримуватись іншими);

2) динаміка довіри (довіра породжує довіру, в той час як недовіра недовіру - ця взаємність може спостерігатись в короткостроковому і в довгостроковому періодах по різному);

3) різниця між вертикальною i латеральною довірою (нею він пояснює страйки та зазначає, що спільноти, де існує i вертикальна i горизонтальна довіра, є радше винятковими).

У системі економічних відносин, як складової соціальних, феномен довіри є:

(C) Боцян Т. В., Зварич Л. В. 
1) основним ресурсом формування та накопичення соціального капіталу, інтегратором, який утворює соціальну цілісність;

2) відображенням актуальних в сучасному та минулому досвіді соціальних взаємодій, що відтворює сформовані традиції, структуру та норми взаємин;

3) прагненням знайти або встановити певну впорядкованість у просторі взаємодії для того, щоб попередити можливі ризики, забезпечити безпеку та взаємовигідність співпраці;

4) інструментом адаптації до соціально-економічних умов різних соціальних груп за рахунок внутрішньогрупової та міжгруповий консолідації;

5) символічним кредитом, який $\epsilon$ однією 3 умов розширення можливостей соціально-економічного життя [Панькова О. В., с. 104].

Ми погоджуємося 3 підходом В. Міхєєвої, згідно якого «довіра є складним феноменом і разом з тим одним із найважливіших чинників, що визначає характер не тільки міжособистісних, а й в цілому усіх соціальних стосунків. Концепція довіри співвідноситься 3 поняттям соціального капіталу. Вона безпосередньо «вплетена» в механізм, що забезпечує інтеграцію і стабільність суспільства» [4, с. 82]

Враховуючи, цінність соціального капіталу 3 одного боку (є елементом, що забезпечує соціальні взаємодії в суспільстві, а соціальна єдність є визначальним фактором стійкого розвитку спільноти), та його структуру з іншого (він складається з горизонтальних зв'язків між людьми i включає соціальні мережі i відповіді норми, які впливають на продуктивність і добробут) можемо констатувати, що ті об’єкти соціального капіталу, що є об’єктами права інтелектуальної власності можемо віднести в обліку до соціальних нематеріальних активів 
Віднесення соціального ресурсу до активів залежить передусім від можливості його оцінки в грошовому вимірнику, що дозволить перенести дане поняття повністю в економічний сектор.

Порівняно 3 фізичним, людським або інтелектуальним капіталом соціальний капітал передбачає принципово важливі механізми та стратегії, що виникли у зв'язку з його специфікою як загального блага. Спеціальні цільові інвестиції в соціальний капітал можливі лише в дуже обмежених межах (затрати часу на підтримання неформальних контактів, представницькі витрати). Проте в більшості випадків його формування являє собою побічний ефект інвестицій в інші види ресурсів, насамперед в людський капітал (в деякій мірі можемо говорити про трансформацію одного виду капіталу в інший). Тому доцільно використовувати термін не «створення» чи «формування» соціального капіталу, а радше «зміцнення» чи «культивування», тобто створення умов для його збереження і розвитку [16, c. 266-267].

Наступне питання: в якій мірі i за допомогою яких механізмів можливо цілеспрямовано вплинути на процес зміцнення соціального капіталу.

Що стосується накопичення соціального ресурсу, то тут варто звернутись до прагматичної теорії, етики наприклад, що враховує феномен цілі, якщо мова йде про цінності, до яких відноситься соціальний капітал. «Все, що зробила або може зробити етика, полягає не у визначенні безумовних обов'язків, а у визначенні того, яка 3 кількох альтернатив, можливих в даних умовах, призведе до кращих наслідків» [5, с. 67]. Проте тут стає питання про двоякість поняття «соціальний ресурс», де з одного боку від є ресурсом, а з іншого самою ціллю, продуктом, що утворюється. Тобто він $є$ ціннісно-цільовим феноменом, а його концепція $\epsilon$ прагматичною, а не позитивною чи нормативною. Соціальний ресурс, як поняття, виражений в грошових одиницях $\epsilon$ цінністю, що забезпечує (C) Боцян Т. В., Зварич Л. В. 
ефективне рішення проблем та сталого розвитку як соціальних спільнот так і суспільства в цілому. В такому баченні соціального капіталу ми підтримуємо з одного боку ідеї, відповідно до яких соціальний капітал розглядають як товар або спосіб, що дозволяє максимізувати корисність $\mathrm{i}$ знизити транзакційні витрати [11, с. 24], а з іншого - які під ним розуміють здатність до самоорганізації та спільних дій заради загального блага [9].

Тобто соціальний капітал забезпечує створення цінності через відносини суб'єкта бізнесу з іншими особами, основою яких є довіра.

Довіра в сфері готельного бізнесу між представниками бізнесу i партнерами та клієнтами може бути забезпечена лише в разі надання якісних послуг. Тобто, довіра щодо якості послуги готельного бізнесу забезпечує створення соціального ресурсу.

Забезпечення довіри, може бути реалізоване також через концепцію корпоративної соціальної відповідальності (КСВ), як форми інвестиції в соціальний капітал. Узагальнюючи напрями та потенційні переваги від впровадження заходів КСВ нами [2, с. 36] виділено чотири основні види соціально-відповідальних дій:

1) по відношенню до найманих працівників, в тому числі i потенційних;

2) дії по відношенню до спільноти;

3) дії по відношенню до інших суб'єктів бізнесу, в тому числі і потенційних;

4) захист навколишнього середовища.

В цих напрямах затрати на соціальні програми збільшують витрати в поточному періоді, проте в довгостроковій перспективі вони забезпечують стабільність доходів. Крім того, соціальні програми підвищують лояльність найманих працівників, споживачів, постачальників та суспільства в цілому, що призводить до зростання вартості соціального peсурсу. Саме це і є стимулом для впровадження заходів з КСВ та (C) Боцян Т. В., Зварич Л. В. 
обумовлює необхідність відображення даних заходів у системі обліковоаналітичній системі.

Висновки і перспективи подальших досліджень. Незважаючи на широку варіативність поняття «соціальний капітал» в літературі, в рамках даної роботи, нами визначено соціальний капітал як «якість соціальних відносин», оскільки реалізовується він у взаємовідносинах.

Наявність даного ресурсу мінімізує транзакційні витрати. Як результат i власники готелю i його клієнти, що отримали послугу набувають порівняльну перевагу в конкурентній боротьбі по відношенню до тих, хто знаходиться за межами радіусу довіри. Це на мікроекономічному рівні. На макроекономічному рівні ефективним $€$ розширення «кола довіри». У цьому випадку соціальний ресурс набуває виразної форми суспільного блага Враховуючи, цінність соціального капіталу з одного боку (є елементом, що забезпечує соціальні взаємодії в суспільстві, а соціальна єдність є визначальним фактором стійкого розвитку спільноти), та його структуру 3 іншого (він складається 3 горизонтальних зв'язків між людьми і включає соціальні мережі і відповіді норми, які впливають на продуктивність і добробут) можемо констатувати, що ті об’єкти соціального капіталу, що є об'єктами права інтелектуальної власності можемо віднести в обліку до соціальних нематеріальних активів.

Наступне питання: в якій мірі і за допомогою яких механізмів можливо цілеспрямовано вплинути на процес зміцнення соціального капіталу.

Визначено, що доцільно використовувати термін «зміцнення» чи «культивування» соціального капіталу, тобто створення умов для його збереження і розвитку замість понять «створення» чи «формування» соціального капіталу. Встановлено, що соціальний капітал забезпечує створення цінності через відносини суб'єкта бізнесу з іншими особами, основою яких є довіра.

(С Боцян Т. В., Зварич Л. В. 
Довіра в сфері готельного бізнесу між представниками бізнесу i партнерами та клієнтами може бути забезпечена лише в разі 1) надання якісних послуг; 2) за рахунок постійної активність в сфері КСВ.

В майбутньому розробка теорії соціального ресурсу та механізмів інвестування в нього здатна істотно розкрити концепцію сталого розвитку.

\section{Список використаних джерел:}

1. Андрущенко Г.І. Характер та особливості взаємозв'язку довіри i соціального капіталу / Г.І. Андрущенко // Український соціум. - 2010. - № 2. - C. $7-12$

2. Боцян Т. В. Корпоративна соціальна відповідальність через призму обліково-аналітичного забезпечення менеджменту: основні проблеми / T. В. Боцян // Вісник соціально-економічних досліджень. - 2013. - Вип. 1. - С. 34-39. - Режим доступу: http://nbuv.gov.ua/UJRN/Vsed_2013_1_6.

3. Варинський В.О. Політичний механізм активізації соціального капіталу // Дис. к.політ. наук, Південноукраїнський національний педагогічний університет імені К. Д. Ушинського, Одеса — 2015 http://www.pdpu.edu.ua/doc/vr/varinskij/dis.pdf

4. Міхеєва В. В. Довіра як феномен соціальної реальності / В. В. Міхеєва // Вісник Нац. юрид. акад. України ім. Ярослава Мудрого. Серія : Філософія, філософія права, політологія, соціологія. - 2014. - № 1. - С. 7683

5. Мур Дж. Principia etica // Природа моральной философии. М., 1999

6. Панькова О. В. Доверие как основа формирования социального капитала в контексте развития человеческого потенциала Украины / О. В. Панькова // Актуальні проблеми соціології, психології, педагогіки. - 2012. - № 16. - С. 101-109, c. 104

7. Патнам Р. Гра в кеглі наодинці : занепад соціального капіталу Америки [Електронний ресурс] // Незалежний культурологічний часопис (C) Боцян Т. В., Зварич Л. В. 
«̈̈». - 2001. - № 21. $\quad$ - $\quad$ Режим доступу : http://www.ji.lviv.ua/n21texts/putnem.htm

8. Патнам Р. Д. Творення демократії: Традиції громадянської активності в сучасній Італії / Р. Д. Патнам, Р. Леонарді, Р. Й. Нанетті; [пер. 3 англ. В. Ющенко]. - К. : Основи, 2001. - 302 с

9. Полищук Л. И., Меняшев Р. Ш. Экономическое значение социального капитала // Вопросы экономики. 2011. № 12. С. 46-65

10. Радаев В. В. Понятие капитала, формы капиталов и их конвертация / В. В. Радаев // Общественные науки и современность. 2003. - № 2.- C. 5-16.

11. Татарко А. Н., Лебедева Н. М. Социальный капитал: теория и психологические исследования. Монография. М.: РУДН, 2009, с. 233

12. Фукуяма Ф. Великий разрыв / пер с англ. под общ. ред А. В. Александровой. М.: АСТ: АСТ МОСКВА, 2008. с. 474

13. Фукуяма Ф. Доверие: социальные добродетели и путь к процветанию / пер с англ. М.: ООО «Издательство АСТ»: ЗАО НПП «Ермак», 2004. 730 с.

14. Юхименко-Назарук I. А. Теоретичні основи бухгалтерського обліку мережевого капіталу: інституційний аспект / I. А. ЮхименкоНазарук // Економічний вісник Запорізької державної інженерної академії. - 2017. - Вип. 3. - С. 159-164. - Режим доступу: http://nbuv.gov.ua/UJRN/evzdia_2017_3_34.

15. Baron S., Field J., Schuller T. (2000) Social Capital: Critical Perspectives. OUP Oxford, p. 320

16. Boeck T., Fleming J. Social Policy - a Help or a Hindrance to Social Capital // Social Policy and Society. 2005. Vol. 4. №3., 2005

17. Fox A. Beyond Contract: Work, Power and Trust Relations / Faber \& Faber, 1974. $408 \mathrm{p}$ 
18. Fukuyama F. Trust: the Social Virtues and the Creation of Prosperity 1995, New York The free press, $457 \mathrm{p}$.

19. Putnam R. Bowling Alone: The collapse and revival of American community / R. Putnam. - New York : Simon and Schuster, 2000. - 384 p.

\section{REFERENCES:}

1. Andrushchenko H.I. (2010) Kharakter ta osoblyvosti vzaiemozviazku doviry i sotsialnoho kapitalu [The nature and features of the relationship of trust and social capital] // Ukrainskyi sotsium. - 2010. - № 2. - S. 7-12 [In Ukrainian]

2. Botsian T. V. (2013) Korporatyvna sotsialna vidpovidalnist cherez pryzmu oblikovo-analitychnoho zabezpechennia menedzhmentu: osnovni problemy [Corporate social responsibility through the prism of accounting and analytical management support: the main problems] // Visnyk sotsialnoekonomichnykh doslidzhen. - Vyp. 1. - $\quad$ S. 34-39 http://nbuv.gov.ua/UJRN/Vsed_2013_1_6 [In Ukrainian]

3. Varynskyi V.O. (2015) Politychnyi mekhanizm aktyvizatsii sotsialnoho kapitalu [Political mechanism of social capital activating] // Dys. k.polit. nauk, Pivdennoukrainskyi natsionalnyi pedahohichnyi universytet imeni K. D. Ushynskoho, Odesa - http://www.pdpu.edu.ua/doc/vr/varinskij/dis.pdf [In Ukrainian]

4. Mikheieva V. V. (2014) Dovira yak fenomen sotsialnoi realnosti [Trust as a phenomenon of social reality] // Visnyk Nats. yuryd. akad. Ukrainy im. Yaroslava Mudroho. Seriia : Filosofiia, filosofiia prava, politolohiia, sotsiolohiia. - № 1. - S. 76-83 [In Ukrainian]

5. Mur Dzh. (1999) Principia etica // Pryroda moralnoi fylosofyy. M. [In Russian]

6. Pankova O. V. (2012) Doverye kak osnova formyrovanyia sotsialnoho kapytala $\mathrm{v}$ kontekste razvytyia chelovecheskoho potentsyala Ukrainy [Trust as (C) Боцян Т. В., Зварич Л. В. 
the basis for the formation of social capital in the context of the development of the human potential of Ukraine] // Aktualni problemy sotsiolohii, psykholohii, pedahohiky. - № 16. - S. 101-109 [In Russian]

7. Patnam R. (2001) Hra v kehli naodyntsi : zanepad sotsialnoho kapitalu Ameryky [Elektronnyi resurs] [Bowling Alone: The collapse and revival of American community] // Nezalezhnyi kulturolohichnyi chasopys «I». - № 21. Rezhym dostupu : http://www.ji.lviv.ua/n21texts/putnem.htm [In Ukrainian]

8. Patnam R. D. (2001) Tvorennia demokratii: Tradytsii hromadianskoi aktyvnosti $\mathrm{v}$ suchasnii Italii [Creation of Democracy: Traditions of Civic Activity in Contemporary Italy] [per. z anhl. V. Yushchenko]. - K. : Osnovy, 2001. - 302 s [In Ukrainian]

9. Polischuk L. I., Menyashev R. Sh. (2011) Ekonomicheskoe znachenie sotsialnogo kapitala [The economic significance of social capital] // Voprosyi ekonomiki. - № 12. - S. 46-65 [In Russian]

10. Radaev V. V. (2003) Ponyatie kapitala, formyi kapitalov i ih konvertatsiya [The concept of capital, the forms of capital and their conversion] // Obschestvennyie nauki i sovremennost. - № 2.- S. 5-16. [In Russian]

11. Tatarko A. N., Lebedeva N. M. (2009) Sotsialnyiy kapital: teoriya i psihologicheskie issledovaniya [Social capital: theory and psychological research]. Monografiya. M.: RUDN, p 233 [In Russian]

12. Fukuyama F. (2008) Velikiy razryiv [Great break]/ per s angl. pod obsch. red A. V. Aleksandrovoy. M.: AST: AST MOSKVA, 2008. s. 474 [In Russian]

13. Fukuyama F. (2004) Doverie: sotsialnyie dobrodeteli i put k protsvetaniyu [Trust: social virtues and the path to prosperity] / per s angl. M.: OOO «Izdatelstvo AST»: ZAO NPP «Ermak», 730 c. [In Russian]

14. Iukhymenko-Nazaruk I. A. (2017) Teoretychni osnovy bukhhalterskoho obliku merezhevoho kapitalu: instytutsiinyi aspekt // Ekonomichnyi visnyk Zaporizkoi derzhavnoi inzhenernoi akademii. - 2017. (C) Боцян Т. В., Зварич Л. В. 
Vyp. 3. - - S. 159-164. - $\quad$ - Rezhym dostupu: http://nbuv.gov.ua/UJRN/evzdia 2017334 [In Ukrainian]

15. Baron S., Field J., Schuller T. (2000) Social Capital: Critical Perspectives. OUP Oxford, p. 320

16. Boeck T., Fleming J. (2005) Social Policy - a Help or a Hindrance to Social Capital // Social Policy and Society. Vol. 4. №3.

17. Fox A. (1974) Beyond Contract: Work, Power and Trust Relations / Faber \& Faber, $408 \mathrm{p}$

18. Fukuyama F. (1995) Trust: the Social Virtues and the Creation of Prosperity, New York The free press, $457 \mathrm{p}$.

19. Putnam R. (2000) Bowling Alone: The collapse and revival of American community. - New York : Simon and Schuster. - 384 p. 